\title{
CURRENT STUDIES ON HYDROLOGY IN JAPAN
}

\section{Sôki YAMAMOTO*}

This is a brief review of the geographers' contributions to hydrology in Japan made after 1969. The author had already published reviews in $1966^{1)}$ and $1968^{2)}$ on the same topic.

A commission on hydrology was established in 1967 in the Association of Japanese Geographers (Nippon-Chiri-Gakkai). This commission (Chairman: Yokichi Mino-Ishikawa), corresponding to the Commission on IHD in IGU, stimulated many hydrologic and hydrographic studies in Japan. Taking this opportunity of issuing a special volume for hydrology in the Geographical Review of Japan (Chirigaku Hyoron), the author compiled a summary of the original articles on hydrology by geographers. The purposes of this paper is restricted only to show the current trend of hydrologic researches through published works without making any comments on item.

Titles of all full papers published since 1968 to 1971, as well as short summaries and abstracts during this period are listed on the last pages of this volume.

He expresses his sincere thanks for their kind collaboration to Messrs. Isamu Kayane, Shigemi Takayama, Tadashi Arai, Makoto Aramaki, Kazuki Mori, Noboru Hida and Masahiro Shôda.

During this period, two attractive international conferences were organized and worked out by geographers. The first one was the International Conference on Land Subsidence ${ }^{3)^{4}}$ in Tôkyô in 1969 (President: Kiyoo Wadati, General Secretary: Sôki Yamamoto) and the second was the Asian Regional Conference of the International Association of Hydrogeologists in Tôkyô in 1971 (President: Sôki Yamamoto).

One book entitled "Water Circulation on Alluvial Fan"5) was published in 1971. This book shows a top stage of progress in the systems approach to hydrology and geography with various new technics, including tritium analysis and electric analog models. They discussed ground water balances in connection to surface water on the Kurobe Fan, Toyama Prefecture.

\section{Potamology and Fluvial Geomorphology}

Quantitative description of the drainage basin such as basin hypsometry and Horton's laws $^{6)}$ of drainage network has been a major concern in Japan. Pointing out the fact

Geographical Review of Japan 45-2 1972 * Tôkyô Kyôiku University

( $\mathrm{J}$ : written in Japanese, JE : in Japanese with English summary, E : in English)

1) Yamamoto, S. (1966): General view of hydrology in Japan. Japanese Geography. The association of Japanese Geographers, Special Publication, No. 1, pp. 37-42 (E).

2) Yamamoto, S. (1968): Current studies on hydrology in Japan. Geographical Review of Japan, vol. 41-11, pp. 704-711(E).

3) Japan Organizing Committee: Land subsidence in Japan. p. 17, Tôkyô.

4) IASH : Land subsidence, vol. I, II, IASH Publication No. 88.

5) Kayane, I. and S. Yamamoto: Water circulation in the alluvial fan. Kokon-Shoin, Tôkyô, p. 151(J).

6) Kayane, I. (1971): On the theory of physical geography-a review report of researches on stream 
that the bifurcation ratio decreases, with the stream order, Tokunaga ${ }^{7)}$ offered a modified equation for Horton's first law and defined a new bifurcation ratio under two assumptions concerning the areal distribution of non-effective streams which flow' in the main stream without increasing its stream order. By his equation the concavity of Horton's first law is more rigorously expressed on the Horton diagram than the original one. Scale effect of topographical maps for the first law was investigated by Takayama ${ }^{8)}$. His conclusion is that no appreciable change occurs in the mean bifurcation ratio of a drainage basin though the number of first order streams increases with map scale used. It is interesting to know that the Horton's first and second laws are found to be applicable to artificial irrigation canals ${ }^{9}$. Horton's laws were also used by Nishizawa ${ }^{10)}$ to characterize geometric features of a drainage basin and an equation relating the rate of base flow to drainage area is deduced. Geometric characteristics of drainage basins in Japan having an area of more than $150 \mathrm{~km}^{2}$ are measured and calculated by Sakaguchi ${ }^{11}$. Values of drainage area, length of trunk stream, mean width, mean and maximum elevations, median relative elevation, relief ratio, form factor, hypsometric integral, and drainage slope for these drainage basins are presented in a table. Sakaguchi $^{12)}$ also investigated Hack's relation, which relates the length of trunk river $L$ with the area of drainage area $a$ as $L=c a^{n}$, where $c$ and $n$ are constants, for 498 world rivers and 376 Japanese rivers as well as 440 small basins in Hokkaidô. The average value of $n$ obtained is 0.55. Some statistical characteristics of drainage basins in Japan were also investigated in the same paper. Ôya has been conducting researches on geomorphic classification of alluvial plains to investigate the influence of human factors which intensify flood damages in an inundated area ${ }^{13) 14) 15}$.

Researches relating to runoff cover diverse topics. Kusanagi and Fukuda ${ }^{16)}$ applied the convolution integral to relate precipitation with runoff. A form of response function was obtained as a solution of simultaneous equations. New empirical lag time formula of basin

order, Tôkyô Geogr. Papers XV, pp. 71-84.

7) Tokunaga, E. (1966): The composition of drainage network in Toyohira-River basin and valuation of Horton's first law. Geophys. Bull. Hokkaidô Univ. 15, pp. 1-19.

8) Takayama, S. (1971) : Map scale effect on the stream order analysis. Geogr. Rev. Japan, 45 (2).

9) Yamabe, K. (1971): A consideration on hydraulic geometry of streams. Net. Temp. Res. 15 (2), pp. 31-37.

10) Nishizawa, T. (1970) : Discharge and hydrological similarity of drainage basins. Geogr. Rev. Japan, 43, pp. 527-534.

11) Sakaguchi, Y. (1971) : Characteristics of the drainage basins of Japan. Misc. Rept. Res. Inst. Nat. Resour., No. 75, pp. 61-72.

12) Sakaguchi, Y. (1969) : Development of drainage basin-an introduction of statistical geomorphology-. Bull. Dept. Geogr. Univ. Tôkyô, No. 1, pp. 67-74.

13) Ôya, M. (1969) : Geomorphology and flooding of the plain in the middle and lower reaches of the Tone River in Kantô Plain. Chigaku-Zasshi (Jour. Geogr.) 78, pp. 341-354.

14) Ôya, M. (1970): Land use control and settlement plans in the flooded area of the city of Nagoya and its vicinity, Japan. Geoforum 4, pp. 27-35.

15) Ôya, M. and Nakamura, S. (1969) : Geographical study on the inundation caused by the local rainfall in the Neyagawa River near Ôsaka. Misc. Rept. Res. Inst. Nat. Resour., No. 72, pp. 13-32.

16) Kusanagi, Y. and Fukuda, K. (1970) : Numerical solution of runoff prediction by Wiener's theory (I) and (II). Tech. Bull. faculty of Agr., Kagawa Univ. 21 48, pp. 156-165. 
runoff was proposed by Kotôda ${ }^{17)}$. This formula is applicable to a wide range of flood conditions taking the effect of rainfall excess into account. An investigation on the relationship between droughty discharge of streams and meteorological conditions such as duration of drought, annual amount of precipitation and seasonal distribution of days without precipitation was carried out by Ichikawa et al. $^{18)}$ for major rivers in the Kantô District. Tamiya's paper discusses about changes in runoff ratio, peak discharge, lag time of runoff, and flood caused by urbanization. A linear relation is found between runoff or peak discharge with an index of urbanization.

Problems on the river-bed variation were investigated by Mitsui ${ }^{19)}$ and three types were distinguished as follows: a) Aggradation type having an accumulation rate of more than 10 $\mathrm{cm} / \mathrm{yr}$. Rivers, Tone, Watarase, Jôganji, Kiso and Abe are classified in this group. b) Stable type having an accumulation rate of several millimeters to several centimeters in a year, including Rivers Yoshino and Kuzuryû. c) Degradation type showing annual erosion of 4-5 centimeters. Rivers, Chikugo, Ishikari, and Tama fall in this group. It is interesting to see that the type a) is found in drainage basins in youth stage belonging to the Inner Zone, a geological zone of Japan, whereas the type c) is found in those in mature or old stage belonging to the Outer Zone. Satô ${ }^{20)}$ also made clear changes in river bed and pointed out that the effect of gravel mining in lowering river bed was remarkable. Trials were made by $\mathrm{Hara}^{21)}$ to find an experimental equation expressing the salinity distribution in an estuary both for the longitudinal and vertical cross sections of a river. Mitsui ${ }^{22}$ made a classification of Japanese rivers by using the shape of salt wedge.

Research into water temperature has been one of the actively studied fields in hydrology in Japan. Nishizawa ${ }^{23)}$ elucidated that the relation between water temperature and air temperature in a heavy snow region (Takinami River, Fukui Pref.) was shown by three discontinuous linear regression lines during the increasing temperature period. The same relation was also found by Nishizawa ${ }^{24)}$ for the Ara and No-gawa Rivers. Taking into account the effect of subsurface flow from in heavy snow region, he interpreted this phenomenon as caused by a steplike change in the relation of air temperature with water

17) Kotôda, K. (1969) : On the time lag of peak discharge in a small basin. Tôkyô Geogr. Papers, XIII, pp. 139-149.

18) Ichikawa, M., Hirata, S., Hara, A. and Kobayashi, T. (1967): On the relationships between droughty discharge of streams and precipitation in the major drainage basins of Kantô District, Japan. Tôkyô Geogr. Papers, XIII, PP. 89-101.

19) Mitsui, K. (1970) : Problems on the variation of river-bed in Japan. Misc. Rept. Res. Inst. Nat. Resour., No. 73 , pp. 1-8(E).

20) Satô, N. (1971) : Changes of river bed in three main rivers in Nishi-Ôu District, Northern Honshû. Geogr. Rev. Japan, 44, pp. 356-365 (JE).

21) Hara, A. (1971) : Distribution of salinity in an estuary. Sci. Rept. Tôkyô Kyôiku Daigaku, Sec. C., 10 (102), pp. 277-352(E).

22) Mitsui, K. (1971) : On the salt wedge type of Japanese Rivers. Sci. Rept. Fac. Liter., Hôsei Univ., No. 16, pp. 29-44(J).

23) Nishizawa, T. (1969) : Temperature and heat balance of river water during the snow-melting season in the Takinami River Basin. Tôkyô Geography Papers, XIII, pp. 191-200 (JE).

24) Nishizawa, T. (1971) : River water temperature during the ablation season. Tôkyô Geography Papers, XV, pp. 163-168 (JE). 


\section{temperatures.}

A comparison was made by Nishizawa ${ }^{25)}$ concerning the change in characteristics of annual variation of river water temperature downstream of an artificial reservoir before and after the construction of the reservoir. Yamabe ${ }^{26)}$ made a statistical study of river temperature in a mountainous region in order to predict monthly mean river water temperature. Ishikawa ${ }^{27)}$ studied diurnal and downstream-directional changes in river water temperature from the standpoint of cold water damage in rice paddy fields.

\section{Limnology}

An interesting research in applied limnology was conducted by members of the Laboratory for Water Temperature ${ }^{28) 29}$. This is a destratification experiment in an artificial reservoir by injecting air into water in order to induce forced mixing. The results are important not only for solving cold water problems downstream of the reservoir, but also as an effective means to improve water quality in the bottom layer of the reservoir.

As for diffusion coefficient and advective heat, Arai et al. $^{30}$ ) further evaluated the obtained results by comparing them with those in the United States. Another research was made for the Sagami Reservoir by Mori ${ }^{31)}$, who investigated the formation process of density current from inflowing river water and made clear the existance of circulation in the reservoir. Also, special characteristics of this reservoir were revealed by calculating the coefficient of eddy conductivity.

Horiuchi et al..$^{32)}$ investigated the Ketakura-numa Lake Group to distinguish lake types. He also made clear the basic thermal properties of Lake Kawaguchi on the basis of seasonal heat budget observation ${ }^{33)}$. Lake evaporations calculated by a few methods were compared. Ambe et $\mathrm{al}^{34)}$. analyzed ABS concentration of lake waters in a recreational area in order to predict future pollution. Special character of Lake Yu-no-ko, about $90 \%$ of its inflow

25) Nishizawa, T. \& K. Yamabe (1970): Change in downstream temperature caused by the construction of reservoirs (I). Science Rept. Tôkyô Kyôiku Daigaku, C, 10 (100), pp. 237-252 (E).

26) Yamabe, K. (1970) : Water temperature of rivers from a mountainous region. Wat. Temp. Res., 14 (4), pp. 42-47 (J).

27) Ishikawa, I. (1970): Diurnal changes of water temperature in a stream-A survey of the Natori river and an irrigation canal-. Science Rept. Tôhoku Univ., 7, 19 (2), pp. 181-192 (E).

28) Research Section of Laboratory for Water Temperature (1969): Review of researches on the method of forced mixing in the reservoir. Water Temp. Res. 13 (3), pp. 7-18 (J).

29) Arai, T. \& T. Okino (1968) : On the experiment on destratification of reservoir water by air-bubbling (1). Misc. Rept. Res. Inst. Nat. Resour. 70, pp. 1-9 (JE).

30) Arai, T. (1971): On the experiment on destratification of reservoir water by air-bubbling (2). Misc. Rept. Res. Inst. Nat. Resour. (75) pp. 50-60 (JE).

31) Mori, K. (1970): On the depth of inflowing layer of river water in the Sagami Reservoir. Jap. Jour. Limnol., 31 (4), pp. 111-128 (JE).

32) Horiuchi, S. and Taba, Y. (1970) : Limnological study on the Ketakura-numa Lake Group. Report for Water Resources Evaluation of Japanese Volcanoes, II, pp. 42-44 (J).

33) Horiuchi, S. (1970) : Heat budget of Lake Kawaguchi, Report for hydrological studies on water balance of river and ground water in Tôkyô Metropolitan District. No. 3, pp. 126-130 (J)

34) Ambe, Y. \& T. Han'ya (1968): ABS contents in the waters of Lake Yu-no-ko and Lake Haruna. Kôgyô Yôsui . (Industrial Water), 121, pp. 41-42 (J). 
being supplied from ground water, was revealed by $\mathrm{Arai}^{35)}$ through a water balance study. Arai ${ }^{36)}$ also observed the absorption of short wave radiation in water, which relates to heat exchange in the subsurface layer as well as biological activities in the lake, by using his own water-proofed pyranometer. Horie have been conducting paleo-limnological studies through the analysis of lake bottom sediment ${ }^{37388}$.

A different approach was made by Saijô et al. ${ }^{39)}$ on the basis of lake metabolism. It is of value because they could make clear the cycles of nitrogen, carbon and phosphor in Lake Biwa.

\section{Geohydrology}

Studies on the mode of occurrence of groundwater in Japan has been carried on by many authors such as on non-confined water in the Myôshôji River ${ }^{40)}$ and Tama River ${ }^{41}$ by N. Naganuma, in the Ômama Fan by G. Ayuba ${ }^{42)}$, in the Shônai River ${ }^{43)}$ and the Nasuno $F^{44)}$ by S. Yamamoto. In the Tama River and the Ômama Fan areas, pH, water temperature, electric conductivity etc. of ground water were measured. On the Shônai River, S. Yamamoto discussed the relation between ground water and surface water using data of ground water height and river discharge. Kuwabara ${ }^{45)}$ also made the same survey in the Chichibu Basin and Ishikawa et al. ${ }^{46)}$ prepared the same type monograph of ground water in the Ôguri River Basin.

Fukuda ${ }^{478)}$ is carrying on a study of ground water table fluctuation in paddy fields in

35) Arai, T. (1970): Observation results in the water and mad temperatures in Lake Yu-no-ko. Ann. Rept. Inst. Human Sci., Rissho Univ., No. 8, pp. 84-87 (J).

36) Arai, T. (1969) : Preliminary observatoin on epilimnitic heating of lake water. Misc. Rept. Res. Inst. Nat. Resour. 72, pp. 6-12 (JE).

37) Horie, S. (1969) : Characteristics of world ancient lakes-viewed from the result of analysis of sediment materials. Ann. Rept. Lab. Dis. Prev., 12 B, pp. 231-236 (JE).

38) Horie, S. (1969) : Late pleistocene limnetic history of Japanese ancient lakes Biwa, Yogo, Suwa, and Kizaki. Mitt. Internat. Verein. Limnol., 17, pp. 436-445 (E)

39) Saijô, Y. \& M. Sakamoto (1970) : Primary production and metabolism of lakes-Some normal and specialized examples from Japan-. Profiles of Japanese Science and Scientists, pp. 207-225 (E).

40) Naganuma, N. (1969) : On shallow ground water in the Myôshôji River area. Sci., Rept., Fac. Literature, Komazawa Univ. No. 27, pp. 40-57 (J).

41) Naganuma, N. (1970): On ground water in an alluvial plain, with special reference to that on right bank area of the R. Tama. Water Temp. Research, 13-15, pp. 2-13 (J).

42) Ayuba, G. (1970): Studies on geomorphology and free ground water conditions. Sci. Rept. Fac. Literature, Komazawa Univ. No. 28, pp. 107-129 (J).

43) Yamamoto, S. (1969): The ground water hydrology of river valley (6), with special reference to the R. Shônai, Aichi Pref. Tôkyô Geogr. Papers, XIII, pp. 53-64 (JE).

44) Yamamoto, S. (1971): The ground water hydrology of Fan. Kokonshoin, Tôkyô p. 159-180 of Fan.

45) Kuwabara, M. (1969) : Ground water in the Chichibu basin. Misc. Rept. Research Inst. Natural Resources, 72 , pp. 33-42 (J).

46) Ishikawa, Y., Takayama, S., Takamura, H. and K. Sekine (1968) : Ground water on the River Ôguri basin, Tama Hill. Bull. Literature, Risshô Univ. 32, pp. 26-59 (J).

47) Fukuda, K. (1970): Fluctuation of water table of the shallow ground water of paddy fields in the downstream basin of the Aya river. IASH Publ. No. 96, pp. 56-69 (E).

48) Fukuda, K., Izutsu, K. and T. Maekawa (1970): Variation of water table fluctuation in paddy fields 
the lower reach of the $\mathrm{R}$. Aya, Kagawa Prefecture. He discussed the relation between $\mathrm{aR} / \mathrm{AR}$ ( $\mathrm{aR}$ means area that has the depth of $\mathrm{D}$ to water table and $\mathrm{AR}$, total area) and $\mathrm{D}$, reaching to the conclusion that this showed a logarithmic-normal distribution. He also predicted ground water level by the theory of Wienner-Hopf.

He defined coefficient of variance $(\bar{C})$ on ground water level as a ratio of $\mathrm{d} / \mathrm{M}$, where $\mathrm{d}$ is standard deviation of daily fluctuation of ground water level and $\mathrm{M}$ is mean value, so $d=\left[\frac{1}{n} \sum_{i=1}^{n}=1\left(D_{i}-M_{0}\right)^{2}\right]^{1 / 2} \cdot \quad$ Relation between absolute height of water level and distance from the top of alluvial plain, he obtained the following equations: $\bar{C}=a+b \bar{H} g$, where $\bar{H} g$ means the height of mean ground water level, $\bar{C}=c-d \bar{R}$ where $\bar{R}$ means the distance from the top of alluvial plain.

Yamamoto $^{49)}$ made an extensive survey of hydrology on and around Mt. Fuji, and proposed three diagramatic divisions of the volcano body: upper recharging zone, middle recharging zone and spring zone. He obtained the following equation to show the discharge amount of springs around Mt. Fuji. $Q=-2 \pi a T m A J_{l}(m a) \exp .\left(-m^{2} T t / S\right)$, here $a$ : radius, $T$ : transmissibility coeff., $S$ : storage coeff., $t$ : time and $-(S / T \cdot 1 / \tau \cdot d \tau / d t)=m^{2}$. Time dependant decreasing factor is expressed as $\tau=\tau_{0} \exp .\left(-m^{2} T t / S\right)$. The result obtained from this calculation has fairy good coincidence with the actual measurements.

Mitsui ${ }^{50)}$ pointed out the existence of two separated ground water basins and three aquifers with the depths of $100 \mathrm{~m}, 140-150 \mathrm{~m}$ and deeper than $200 \mathrm{~m}$ respectively on the Arakawa lowland. According to the result of chemical analysis, these ground water bodies were detected as fossil ones of marine origin. He also notices that remarkable decline of pressure head is due to the overpumping of ground water and no one can see a self-flowing well which could be seen before the World War II over this area.

Takamura ${ }^{51)}$ discussed the amount of artesian ground water flow with relation to tidal fluctuation on the lower reach of the $\mathrm{R}$. Tone. He made an investigation of ground water in Kashima and made prediction of lowering of ground water level due to artificial digging of a harbor. Yamamoto ${ }^{52)}$ also treated the problem of necessity of ground water forcasting in Japan.

After finishing an extensive survey of subsurface geology of the Musashino Upland ${ }^{53)}$, Shindô made experiments ${ }^{54}$ on clarifying mechanisms of vertical recharge of confining layers. Immediately after pumping started, recharge by squeeze from upper and bottom storages

shown by coefficient of variance (II). Tech. Bull. Fac. Agr. Kagawa Univ. 21-4, pp. 139-148 (E).

49) Yamamoto, S. (1970) : Hydrologic study of Volcano Fuji and its adjacent areas. Geogr. Review of Jap., 435 pp. 267-284 (JE).

50) Mitsui, K. (1970): On the confined water and change of pressure head in the vicinity of big cities. Recent study of ground water. Memorial Publ. of Prof. G. Sakai, Hirosaki, pp. 105-118 (J).

51) Takamura, H. (1969): On the effects of rainfall and tidal fluctuation to the amount of flowing artesian discharge (No. 1), annual Rept., Human Sci., Risshô Uuiv. No. 7, pp. 78-97 (J).

52) Yamamoto, S. (1970): Ground water forecasting. Water Science, No. 76 (14-5) pp. 12-15 (J).

53) Shindô, S. (1970): Subsurface geology of the Musashino Terrace. Journ. Geogr. No. 774 (78-7), pp. $449-470(\mathrm{JE})$.

54) Shindô, S. (1971) : Study on recharging mechanism of con fined aquifer (I). Sci. Rept. Fac. Engg. Tôyô Univ., No. 6, pp. 9-19 (J). 
always occurs and follows vertical leakage from a separated aquifer through aquiclude. The reverse phenomenon will occur after pumping stopped.

\section{Water Balance}

Three books or monographs on water balance have been published since 1968 edited respectively by R. Keller ${ }^{55)}$, S. Yamamoto ${ }^{56)}$, and M. M. Yoshino ${ }^{57)}$. In the first book, which is the first report of the IGU Commission on IHD containing two papers by Japanese geographers, ${ }^{58) 59)}$ Yamamoto discussed changes in water balance elements caused by rapid denudation of vegetation by military training on the east side of Mt. Fuji. The second one contains papers in a wide variety of hydrological fields, i. e. hydrometeorology, hydro-geomorphology, water quality, geohydrology and water balance contributed from some forty geograrhers. The third one is unique in that the water balance of Monsoon Asia is approached from the field of climatology and meteorology. General introduction of this book is written by Yoshino ${ }^{60)}$ as a review paper of historical development of water balance studies in the Monsoon Asia.

One of the most serious problems in water balance studies is the inaccuracy of observed data especially for mountainous regions. Since the real value is not known for the areal means of evapotranspiration, precipitation, runoff etc., it is necessary to cross-check the observed data in a drainage basin. Kayane ${ }^{61)}$ applied this checking method for the Gônogawa drainage basin and found that a large error is involved in runoff data of flood years whereas variation in annual evapotranspiration is fairly small. Kayane et al. ${ }^{62)}$ further extended this research to other basins and evaluated reliability of annual runoff ratio of Japanese rivers hitherto reported. Their conclusion is that an annual runoff ratio having a value of more than $90 \%$ reported so far is dubious and needs re-investigation.

The climatological water balance studies using the Thornthwaite's method were carried out by Yoshino $^{63)}$ for the Kantô District, by Horiuchi ${ }^{64)}$ for Madagascar, and Kayane ${ }^{65)}$ for

55) Keller, R. ed. (1968) : Run-off regimens and studies of the water balance, Selbstverlag der Geographischen Institute der Albert-Ludwigs-Universität, Freiburg I. Br., Germany p. 240 (GE).

56) Yamamoto, S. ed. (1970) : Hydrological studies on water balance of river and groundwater in the Tôkyô Metropolitan District. Report for the special research grant of the Ministry of Education in 1969. p. 195 (J).

57) Yoshino, M. M. ed. (1971) : Water balance of Monsoon Asia. University of Tôkyô Press, p. 308 (E).

58) Yamamoto, S. (1968): Influence of human activity on the hydrologic cycle. ibid., pp. 15-24 (E).

59) Kayane, I. (1968): Variation in annual runoff ratio. ibid., pp. 25-32 (E).

60) Yoshino, M. M. (1971) : Water blance problems in the Monsoon Asia from the viewpoint of climatology. ibid., pp. 3-23 (E).

61) Kayane, I. (1969) : On the accuracy of data on water balance. Tôkyô Geography Papers XIII, pp. 129-137 (JE).

62) Kayane, I. and Takeuchi, A. (1971): On the annual runoff ratio of Japanese rivers. Geogr. Rev. Japan, 44, pp. 347-355 (JE).

63) Yoshino, M. M. (1969): Water balance in and around the Kantô District. Suiri Kagaku (Water Science), 13, 3, pp. 1-15 (J).

64) Horiuchi, S. (1970) : Climatological characteristics of Madagascar viewed from water balance. Report of Natural Science Institute, Nihon University. No. 5, pp. 31-53 (J).

65) Kayane, I. (1971) : Hydrological regions in the Monsoon Asia, in Yoshino ed. "Water balance of 
the Monsoon Asia aiming at delimiting the regions. Wetness and dryness in the Monsoon Asia are also investigated by Mizukoshi ${ }^{66)}$ and Kawamura ${ }^{67)}$. Classification of water balance characteristics of drainage basins by topography is made by Kaneko ${ }^{68)}$ mostly based on the result of his field surveys.

Water balance of unconfined groundwater is studied by Hirata ${ }^{69)}$ putting emphasis on recharge mechanism. He surveyed the soil moisture change from the surface to ground water table by using the neutron soil moisture meter throughout a whole year as well as other water balance components. His interesting conclusion is that the leakage from waterwork pipes to groundwater amounts to $59 \%$ of the total annual recharge of $690 \mathrm{~mm}$.

Simulation of the confined ground water table in the Kôto deltaic region was made by Yamamoto et $\mathrm{al}^{70)}$, by applying a two-dimentional diffusion model for unconfined ground water. Two important results drawn are 1) the model is applicable to so-called confined ground water, at least on the annual basis, and 2) no appreciable recharge from rainfall can be expected to this ground water basin. The latter result was supported later by Kayane $^{71)}$ through the analysis of some 100 tritium data obtained from many sources. In Fukui City, however, Yamamoto ${ }^{72)}$ clarified that about $80 \%$ of ground water withdrawal was recharged by precipitation. This indicates that the response of ground water to withdrawal is quite different corresponding to hydrologic and hydrogeologic characteristics of the region. Over-pumping of ground water in many industrial districts in Japan has caused serious land subsidence, on which Yamamoto ${ }^{73)}$ made a historical review.

\section{Water Quality and Pollution Problem}

Hirayama $^{74)}$ described the method of water pollution survey on such points as sampling method, measuring items on the spot and others. Ayuba ${ }^{75)}$ investigated chloride contamination of ground water in Ômama by the disposed water of radish pickle making. Contamination was

Monsoon Asia", pp. 287-300 (E).

66) Mizukoshi, M. (1971) : Regional divisions of Monsoon Asia by Köppen's classification of climate. ibid, pp. 259-274 (E).

67) Kawamura, T. (1971) : Representation of moist and dry climate of Monsoon Asia according to climatic indices. ibid. pp. 275-286 (E).

68) Kaneko, R. (1970-71) : Classification of water balance characteristics by topography. Suiri Kagaku (Water Science), $14(2)-\mathbf{1 5}(2)(\mathrm{J})$.

69) Hirata, S. (1971) : Mechanism of unconfined ground water recharge at Hakusan on the Hongô terrace, Tôkyô. Geogr. Rev. Japan, 44, pp. 14-46 (JE).

70) Yamamoto, S., Kayane, I., Aoki, S., Fuji, S. (1969): Simulation of groundwater balance as a basis of considering land subsidence in the Kôtô Delta, Tôkyô. IASH Publ. No. 88, pp. 215-224 (E).

71) Kayane, I. (1971) : Recharge mechanism in the Kantô groundwater basin deduced from tritium concentration in groundwater. Report of Southern Kantô Wide-Area Land Subsidence, pp. 69-100. (J).

72) Yamamoto, S. (1971) : Hydrologic study on groundwater in Fukui city. Tôkyô Geogr. Papers, XV, pp. 253-274 (JE).

73) Yamamoto, S. (1970) : Land subsidence and its problems-with reference to the results of International Symposium on Land Subsidence, Tôkyô, 1969. Chigaku-Zasshi (Jour. of Geogr.), 78, pp. 471482. (JE).

74) Hirayama, M. (1968) : Method for water pollution, Japan. Analyst, 17-2, pp. 238-244 (J).

75) Ayuba, G. (1970): Human contamination of free ground water on the Yabuzuka upland, Gunma Prefecture. Chirigaku Kenkyû Note, 1 pp. 2-10 (J). 
traced by the conductivity distribution of ground water. He proposed the necessity of the improvement of waste water disposal in the process of pickle making. Yada ${ }^{76)}$ pointed out that salt water encroachment into ground water along the sea coast of Gakunan area had occurred along a buried valley under the lava flow. It is notable that a tremendous amount of recovered water is now in use. Nagasawa ${ }^{77)}$ reported that water quality of confined ground water in the eastern Ôsaka district changed with passage of time. It is dependant on the function of pumping equipment. Katô and Shida ${ }^{\text {78) }}$ summarized mean value of chemical contents of ground water on some alluvial fans such as Mamigasaki, Kurobe with separation of confined and nonconfined ground water. Ground water quality also changed with flow and time in these areas. Comparing chemical contents on 1964 and 67, amounts of $\mathrm{Ca}, \mathrm{Mg}, \mathrm{Na}, \mathrm{Cl}$ and $\mathrm{SiO}_{2}$ in non-confined water and that of alkalinity, $\mathrm{Na}, \mathrm{Cl}$ and $\mathrm{SiO}_{2}$ in confined water had increased. Nagasawa and Teraguchi ${ }^{79}$ pointed out that water contamination of the Nishiyoge River along its whole length is growing on. It is mainly due to the waste water from pig sheds, poultry sheds, slaughter houses, domestic sewage and industrial wastes. Relation between electric conductivity $(x)$ and evaporation residue $(y)$ was as follows: $y=$ $0.767 x+18.992$ and between B. O. D. and C. O. D. was as follows : B. O. D. $=0.445$ C. O. D. ${ }^{1 \cdot 465}$ Mitsui $^{80)}$ collected water samples along the R. Edo and analyzed C. O. D., $\mathrm{NH}_{4}-\mathrm{H}, \mathrm{A} . \mathrm{B} . \mathrm{S}$ and $\mathrm{Cl}$ contents of the water on several times in a day and a year. Under the result of experimental data of self-purification capacity and that of environmental charge, he estimated future contamination of this river.

\section{Socio-economic Hydrology}

Hida $^{81)}$ discussed regional characteristics of ground water use for industries, and investigated $^{82)}$ the establishing process of industrial waterworks in Japan. Shirai ${ }^{83)}$ dealt with the problem about urbanization and irrigation water use.

76) Yada, T. (1970) : Salt-water encroachment in the Gakunan district, Shizuoka Prefecture. Japan. Geogr. Review of Japan, 43-9, pp. 567-571. (J).

77) Nagasawa, M. (1970): Aquifers of confined ground water and variation in water quality in eastern Ôsaka. Jap. Journ. Linn., 31-3 pp. 69-81 (JE).

78) Katô, T. and I. Shida (1970): Geochemical study of ground water on fan. Recent study of ground water, Memorial Publ. of Prof. G. Sakai, Hirosaki, pp. 205-220.

79) Nagasawa, M. and T. Teraguchi (1970): Water pollution in small rivers-the Nishiyoge River in Ôsaka Prefecture. Jap. Journ. Limn. 31-2, pp. 47-66 (JE).

80) Mitsui, K. (1970): Reports on the contamination of the surface water of the R. Edo. Rept. Research Inst. Natural Resources, Tokyo, pp. 1-37 (J).

81) Hida, N. (1969): On the regional characteristics of groundwater use for industry in the Gakunan district, Shizuoka Prefecture. Geog. Rev. of Japan, 42 (4), pp. 248-265 (JE).

82) Hida, N. (1970): The established process of industrial water works. Suiri Kagaku (Water Science) 4 (14), pp. 124-140 (J).

83) Shirai, Y. (1971) : Urbanization and irrigation water use - The case of the Hiroshima Metroporitan Area-. Geog. Rev. of Japan, 44 (4), pp. 284-300. (JE). 